same as the distance-10 A.-between layers of atoms along the $c$ axis of insulin. It seems significant, further, that the length of $a$ in pepsin-67 A.referred to the original hexagonal axes, is so similar to that of insulin-74.7 A.-when given hexagonal axes. These two dimensions define a crumpled layer structure in which the molecules are arranged in networks of six-sided rings of the non-planar cyclohexane type which occurs, for example, in diamond and wurtzite. From the side of such a ring projected on to $(0001), a / \sqrt{ } 3$, or $38 \cdot 7 \mathrm{~A}$. in pepsin, and the thickness of the order of $10 \mathrm{~A}$., a length for one radius of the pepsin molecule may be calculated $=20 \mathrm{~A}$. In insulin, the layers are so arranged that atoms in one fall as nearly as possible into the spaces of the one below, which makes a very compact structure. In pepsin we may imagine that the layers of rings are slid relatively to one another, to bring atoms of the lower ring directly beneath those of the upper ring in such a way that each is approximately tetrahedrally co-ordinated. The effective depth of a single layer is then equal to the thickness of the ring system plus the diameter of a single molecule, and may be calculated to be $51 \cdot 2 \mathrm{~A}$., with a spheroidal pepsin molecule of diameter $41 \cdot 2 \mathrm{~A}$. in this direction. A combination of the crystallographically possible ways of sliding the ring systems is able to give the required length of $c$, nine times that of the depth of one layer and fifteen times the $c$ dimension of insulin.

This kind of structure proposed for pepsin is of a very much looser type than that of insulin. Each molecule is surrounded by only four others and there are large channels through which free movement of water and dissolved substances may occur within the crystal structure. On drying, such a structure would collapse, in agreement with the fact that, in contradistinction to insulin, the crystals of pepsin lose their birefringence on exposure to air and only show crystalline X-ray diffraction effects when immersed in the mother liquor. Various observations ${ }^{11}$ suggest that loose 4 co-ordination structure of this kind may be general among certain classes of protein erystals which belong either to a hexagonal type with an axial ratio about $2 \cdot 3$ similar to that of pepsin, or to a cubic type which shows diamond cleavages. Wherever the attraction between the adjacent protein molecules is of the same order of magnitude as that between the protein molecules and the medium, a low co-ordination structure type may be expected. In insulin, on the other hand, where the molecules can be strongly attracted together with the assistance of metal atoms, the structure is very much more condensed and shows a high co-ordination number.

I have to thank Prof. Pyman and Messrs. Boots Pure Drug Co., Ltd., for a gift of the insulin used in this research.

${ }^{1}$ J. Abel, Proc. Nat. Acad. Sci., 12, 132; 1926.

${ }^{2}$ Proc. Leeds Phil. Lit. Soc. 1, 412; 1929.

3 Phys. Rev., ii, 40, 639; 1932

4 J. D. Bernal and D. Crowfoot, Nature, 133, 794; 1934

s Biochem. J., 1596 ; 1934.

${ }^{6} \mathrm{~K}$. Freudenberg, Z. physiol. Chem., 204, 233; 1932

7 J. Abel, E. M. K. Geiling, C. A. Roudler, F. K. Bell and O. Winter steiner, J. Pharm. Exp. Ther., 31, 65; 1927

8 NATURE, 127, 438; 1931. B. Sjögren and T. Svedberg, J. Amer. Chem. Soc., 53, $2657 ; 1931$.

- Private communication to J. D. Bernal.

${ }^{10}$ Unpublished observations of $\mathrm{J}$. D. Bernal.

11 A. F. W. Schimper, Z. Krist., 5, 13i ; 1881 .

\title{
History of the Menthols
}

A $\mathrm{T}$ a joint meeting of the Chemical Society, and the A Glasgow Sections of the Society of Chemical Industry and the Institute of Chemistry, held in the Royal Technical College, Glasgow, on March 15, Prof. John Read, of the University of St. Andrews, gave a lecture entitled "From Governor Phillip to d-neoisoMenthol : the Story of a Research, 1788-1934".

Prof. Read said that it was his intention to select a research paper and show what a rich background it possessed when given its proper setting in the world of things, men and affairs. The paper in question closed a chapter, or perhaps more correctly a book, in the history of the important chemical family of menthols. The usual source of ordinary menthol is the essential oil of the peppermint plant, Mentha piperita, which has been cultivated in Japan for more than two thousand years. The first mention of crystalline menthol was made in 1771 by Gambius, a Dutch botanist. It is now known that this so-called 'mint camphor' is a member of the first of four series of menthols. Prof. Read and Dr. Grubb completed the tale of these four series in the University Chemical Laboratories at St. Andrews on Christmas Day, 1933.

In tracing the trend of events which led up to this chemical climax, Prof. Read reminded his audience that Capt. Cook landed in eastern Australia, hitherto unknown, on April 29, 1770. In his "Journal" he wrote of the landing-place: "The great quantity of New Plants, etc., Mr. Banks and Dr. Solander collected occasioned my giving it the name of Botany Bay'. From the earliest days, indeed, the unique vegetation of this isolated land attracted the interested attention of visitors and settlers. Two- thirds of the native Australian flora belongs to the family Myrtaceæ, which is represented in Europe by a single species. Eucalyptus, the outstanding Australian genus of this family, is a specialised form adapted to the barren and extra-tropical Australian areas ; it developed after the separation of Australia from the tropical lands. Typically Australian, it is virile, aggressive, and an excellent colonist, with all the characteristics of youth.

Some graphic extracts from Dr. John White's "Journal of a Voyage to New South Wales" followed. Dr. White was surgeon-general to the First Settlement, under Governor Phillip, who reached Botany Bay $w$ ith his fleet of marines, officials and convicts on January 20, 1788, after a voyage lasting eight months. The "Journal" shows that the voyage had its romantic aspects as well as its hardships and notes of grimness : "May 28. Departed this life, Ismael Coleman, a convict, who, worn out by lowness of spirits and debility, brought on by long and close confinement, resigned his breath without a pang. August 31. James Baker, a private marine, received 200 lashes for endeavouring to get passed on shore by means of one of the seamen, a spurious dollar, knowing it to be so. . . Many of these young ladies [in a convent in Rio de Janiero] were very agreeable both in person and disposition; and by frequently conversing with them at the grate, we formed as tender an intercourse as the bolts and bars between us would permit of."

The fleet lingered for a month at Rio, before weighing for the Cape of Good Hope. It is said, although Dr. White does not endorse the statement, 
that Governor Phillip took with him from Brazil some prickly pear plants, for the sake of the cochineal insects which infested them. These insects produced the scarlet dye used for the military uniforms of those days. Unfortunately, the insects appear to have perished during the voyage; thus the prickly pear, freed from its insect control, developed eventually into Australia's foremost plant pest.

At that time, oil of peppermint was a much prized specific ; for in the first issue of the Glasgow Advertiser, dated January 27,1783 , it is stated in an advertise. ment that "this elegant preparation", sold by J. Gillies, bookseller, above the Cross, Glasgow, gives immediate relief "in Gouty and Cholicky Pains in the Stomach and Bowels, Low Headachs, and all Disorders arising from wind"'. Dr. White, being short of this oil, found a very efficient substitute in the essential oil distilled from a certain eucalypt growing around Port Jackson-now known as the Sydney peppermint, or Eucalyptus piperita. This is the first recorded instance of the distillation of a eucalyptus oil.

Many years later, in 1900, the Australian chemist, H. G. Smith, isolated the peppermint ketone imparting the characteristic odour to this oil, and called it piperitone. There are about three hundred species of eucalyptus, each kind-as shown by H. G. Smith and R. T. Baker-producing its own characteristic leaf oil : of these more than twenty secrete piperitone. It was then found that, by hydrogenation and dehydrogenation, piperitone could be changed into menthols and thymol, respectively, so that it has become a commercially valuable substance.

Eucalyptus piperitone is invariably a 'left-handed' substance. Soon after Prof. Read became associated with Mr. Smith at Sydney, in 1920, Prof. J. L. Simonsen, working independently at Dehra Dun, in India, discovered 'right-handed' piperitone in the oil of the Indian grass, Andropogon Jwarancusa. These two piperitones, of the northern and southern hemispheres, are identical, except that their molecules are related as object and mirror images.

One interesting result of later researches, carried out at St. Andrews, has led to a way of proceeding, by laboratory processes, from the 'left-handed' Australian piperitone to the 'right-handed' Indian piperitone. It has also been found possible by means of a complicated network of delicate reactions to utilise piperitone as a source of any one of the four series of menthols. Each of the four kinds of menthol exists in a 'right'- and 'left'-handed form, and methods have been devised for producing the 'right-handed' form of ordinary 'mint camphor', which always is 'left-handed' in Nature.

\section{Crossing-Over of Sex Factors in Lebistes}

$\mathrm{W}$ HILE the validity of the sex-chromosome mechanism in relation to sex determination is generally recognised, yet it has become clear from the work of Goldschmidt on Lymantria, Winge on Lebistes, and various other investigations in which intersexes and the crossing-over of sex factors occur, that genes influencing the sex towards maleness or femaleness are also found in the autosomes. Bridges' conception of genic balance applies to many characters, including sex, and it is necessary to suppose that there are many factors in all the chromosomes, some of which tend towards maleness and others towards the female condition. Various divergent views regarding the distribution of such genes in the $X$ and $Y$ and the autosomes are at present held.

In the little fish, Lebistes, in which there is a series of colour patterns inherited through the $Y$-chromosome from father to son, Winge has shown also that the $X$-chromosomes may be altered into autosomes, so that sex-linked genes are inherited as ordinary Mendelian differences. By selecting masculine autosomal genes, $X X$ males were obtained, and by backcrossing a race was produced in which both the males and females were $X X$ in composition and the $Y$. chromosome type of inheritance had been eliminated.

In a recent paper (C.R. Lab. Carlsberg, Série Physiol., 21, No. 1) Winge has carried the subject of sexual balance further. Probably in these fishes, as in pigeons, the difference between the sexes is small, so that the balance of the sex genes is easily upset. This is further shown by the fact that certain matings gave practically only females in winter but equal numbers of the sexes in spring. Nevertheless, conspicuous intersexes seldom appeared. Normally, females show no trace of the colour genes which are transmitted by the males in the $Y$-chromosome, but occasional females appear which show a trace of the male pattern and probably have several masculine genes. In a cross involving the maculatus and lineatus races, $7 X Y$ females appeared having the maculatus spot. Crossed with $X Y$ males they gave, as predicated, 3 males : 1 female. Among these were fertile $Y Y$ males which, when crossed with normal females, gave only male offspring.

There are no unequal pairs of chromosomes in Lebistes, so the $X$ and $Y$ must be of equal size. Among other conclusions reached are that all the genes in $X$ are able to cross over to $Y$, and that the $Y$ contains at one end a specific male-determining gene which is at the same time a gene for colour pattern. The $X$ lacks this gene, but whether it possesses an allelomorphic feminine gene is undecided. R. R. G.

\section{University and Educational Intelligence}

Aberdenn.-The honorary degree of LL.D. has been conferred on the following, among others : Prof. E. V. Appleton, Wheatstone professor of physics, King's College, London; Mr. W. H. Buckler, engaged in archæological work in Asia Minor; Lieut.-Col. A. T. Gage, formerly director of the Botanical Survey of India and superintendent of the Royal Botanic Gardens, Calcutta ; Dr. J. C. G. Ledingham, professor of bacteriology, University of London, and director of the Lister Institute, London.

EDINBURGH.-A gift of $£ 10,000$ has been received from Mr. J. Albert Thomson for the purpose of establishing a commercial laboratory in the University. This will provide for the immediate requirements in staff and equipment for a laboratory providing the approved methods of training for students for the commerce degree, so that those who aspire to the higher positions in industry shall have an intimate working knowledge of all up-to-date office machinery and appliances.

London.-The County Borough Council of West Ham has decided to make a grant of $£ 2,500$, payable over five years, towards the cost of the erection of the new buildings in Bloomsbury. The Worshipful Company of Plumbers has made a donation towards the cost of the Ceremonial Hall to be built on the Bloomsbury site. 